\title{
DOES ICTS MATTERS FOR CORRUPTION?
}

\author{
Caroline Gratia Sinuraya \\ Tutik Rachmawati \\ Parahyangan Catholic University, Bandung \\ E-mail:sinuraya.caroline@live.com,rachmawati.tutik@gmail.com
}

\author{
ARTICLE INFORMATION \\ Article history: \\ Received July 24, 2015 \\ Revised November 30, 2015 \\ Accepted January 26, 2016

\section{JEL Classifications} \\ K42
}

\section{Key Words:}

Information and communications technology

E-Government,

Up-skilling corruption

\section{DOI:}

10.21532/apfj.001.16.01.01.04

\begin{abstract}
Corruption is a common term used in both private and public sector to understand the misused of resources in order to enriched themselves, unlawfully. Corruption has been endemic in Indonesia starting from the highest peak of government to the grass root level. Some organizations had tried to eradicate corruption with any possible way they could find; law enforcement, behavioural to education approach. However, the use of information, technology and communication or ICTS or known as e-Government in eradicating corruption has been considered a break trough. They believe that by implementing ICTS in several sectors of public services, it could help to eradicate corruption in Indonesia. Local Governments has been using e-budgeting but corruption is still prevalent. ICTS serves as way to reduce corruption rate but it does not eradicate corruption at all. The adoption of ICTS in governmental systems creates an opportunity for the officers and staffs who understand and occupies skills of ICTS (e-literate) and at the same time blocks chances for those who do not understand ICTS. This is called as an up-skilling corruption. This paper will discuss e-administration which is understood as the use of information and communication technologies and in particular the internet, as a tool to establish a better-quality administration. Using a case study of e-administration in Bandung City, this paper will discuss how Bandung City is to implement Online Licensing through BPPT or Badan Pengkajian dan Penerapan Teknologi (The Agency Assesment and Application of Technology) with a consideration that there is a chance for up-skilling corruption. Further, upon the discussion, recommendation on how to implement proper e-administration so that it will achieve its goal to eradicate corruption.
\end{abstract}




\section{INTRODUCTION}

Technological advancements have been credited for playing a significant role in the globalization of trade, communication, and life styles $^{1}$. The rapid development of information and communications technologies (ICTSs) is astonishing in how it affects people's lives in many aspects ${ }^{2}$. The utilization of ICTS was initiated by the private sector. In a matter of high-technology, the private sector has always become the first institution using it. E-commerce is one of the examples. Most of the private sector uses this as one of the way to transact to its costumer. The public sector tried to imitated e-commerce and implemented it within the name of electronic government or known as e-Government. Wescott on Choi (2014) argues that ${ }^{3}$ :

Yet the speed and growth rate of electronic usage in the private sector far exceeds that in the public sector. This is not surprising because markets are usually faster to adopt innovative ideas and technologies than the government. In addition, other characteristics inherent to the public sector such as the large scale of costs, institutional inertia of existing rules and structures, and slow changes of working habits prevent the government from quick adoption of ICTS.

Gage on Choi (2014) claimed that ${ }^{4}$ :

ICTs also aims to do the same for

Jamshed J. Mistry and Abu Jalal, (An Empirical Analysis of the Relationship Between E-Government and Corruption, 2012) p. 145

2 Jin-Wook Choi, (E-Governemnt and Corruption: A Cross-Country Survey, 2014), p.217

$3 \quad$ Ibid. p.218.

$4 \quad$ R.D.Pathak et.al (Governance \& CorruptionDevelopments and Issues in Ethiopia, 2007), p.5 interactions between governments and government agencies at national, municipal and local levels (G2G), citizens (G2C), and business (G2B). The use of ICTS in government tries to transcend simply a focus on efficiency and effectiveness. By making available interactive access to and use of information it hopes to empower citizens.

E-Government and ICT are like twin they're the same but differ in some aspect. ICTs -information, communication and technology-is an umbrella term that includes any communication device or application, encompassing; radio, television, cellular phones, computer and network hardware and software, satellite systems and so on as well as the various services and application associated with them ${ }^{5}$, while e-Government is the use of information and communication technologies to transform government by making it more accessible, effective and accountable ${ }^{6}$.

\section{CONCEPTUAL FRAMEWORK AND ANALYSIS}

ICTs offer countries a new approach to creating transparency and promoting anti-corruption. The implementation of e-Government in Indonesia was started in year 2000, but at that time the idea of using e-Government did not come. In April 24 2001 the government released the President Instruction (INPRES) number 6/2001 about

Rouse Margareth, ICTS (information and communications technology-or technologies) definition'

6 The E-Government Handbook For Developing Countries. page. 1 
Telecommunication Media and Informatics to support good governance and to accelerate the democracy process. And then two years after the INPRES was released, President Megawati Seokarno Putrireleased INPRES number 3/2003 about The Policy and E-Government Strategic Development. According to this new regulation the e-Government strategic development is one of many efforts to develop the implementation of electronic-based governance in order to increase the public service quality effectively and efficiently. Based on these regulations, some local government in Indonesia tries to implement e-Government, Bandung City for example.

The Bandung Mayor, Ridwan Kamil and his administration is eager to make Bandung as the Indonesia's Silicon Valley, which without a doubt will implement e-Government in its system. For example The Agency of Assessment and Application of Technology or BPPT, wanting to make a new changes by launching The Online Licensing of The City of Bandung which will include 25 different online license and 10 differences services. By launching this new service, it would be much easier and faster for the Bandung's citizens to apply for a new permit since this system will make bribery and brokering impossible to enter the system ${ }^{7}$.The Online Licensing is another name of e-administration. E-administration ${ }^{8}$

$7 \quad$ Perdana, Putra Prima 2015, ‘ Kini, 24 Jenis Izin di Bandung Bisa Diajukan Secara "Online"” Kompas, May 28, viewed July $182015<$ http://regional. kompas.com/>

8 Roux, Latetia 'Public service values and e-administration: an explosive mix? Illustration drawing on the case of The Familiy allowance Funds (Caisses d'Allocations Familiales) in as a component of e-Government is the use of Information and Communication Technologies (ICTs) and in particular the Internet as a tool to establish a better-quality administration (OECD, 2003). As stated on the previous paragraph, this system would make bribery and brokering impossible to enter the system since it is run through internet or online. Although the new system may prevents the corruption, this new system is still vulnerable of corruption, especially to those who are very familiar with internet or e-literate considering the hypotheses saying that ICTs is not a panacea to eradicate corruption but only helps to decrease the rate. Generally, the introduction of the internet in the administrative proceedings of all fields of public administration brings more access to relevant information and to extract bribes from their clients 9 .

As we know, the corruption in Indonesia is spreading from the central government through the root grass of government. It is happening almost in every sector of public institution in Indonesia, even the parliament, executive and judicative couldn't resist the temptation of multi-billion projects or the bribe. On December $2^{\text {nd }} 2014$, BPK reported on the first semester of 2014, there are nine findings are worth Rp.944,81 billion and 441 findings are worth Rp43,42 trillion since 2003 until the first semester of $2014^{10}$. Below is the total amount of corruption cases, suspect and state deprivation in $2014^{11}$ :

France, 2014), p. 228

9 Sarah on Pathak et.al., op.cit., page 6

10 Tren Pemberantasan Korupsi 2014, Divisi Investigasi Dan Publikasi ICW. P. 5

$11 \quad$ Ibid. p.5 
Figure 1 : Corruption In 2014

\begin{tabular}{|l|l|}
\hline \multicolumn{2}{|c|}{ Corruption Data In 2014} \\
\hline Cases & 629 cases \\
\hline Suspects & 1328 suspects \\
\hline State Deprivation & Rp 5,29 trillion \\
\hline
\end{tabular}

Joe Bologne through his GONE theory stated the four things caused corruption: Greed, Opportunity, Needy and Exposes ${ }^{12}$. Corruption happened because the corruptor never satisfied of what he/she already has in possession, they are greedy. Corruption also happened because there was a hole in the systems or the systems are not sophisticated enough which create an opportunity to corrupt. Need is also a cause of corruption. The human needs are always increase exponentially as year goes by while the income still in the same rate or not enough to fulfil daily needs, or because of the change in life style. A decade ago, the need of smart phone was very low compared to today's situation. Some people see this phenomenon of having the latest smart phone very "seriously", while in the other hand they do not have enough money to fulfil their needs. Some people chose to corrupt while others prefer to work harder. Last but not least is exposes which relates to the lack of punishment for corruptor.

Pathak et.al (2007) $)^{13}$ on his article (Governance \& Corruption: Developments and Issues in Ethiopia) explained that corrupt action are so diverse and the concept of corruption so generic that any precise and detailed definition

12 Roeshanny, GONE Theory, viewed May 62015 $<$ https://roeshanny.wordpress.com/2009/02/04/ gone-theory/>

13 Pathak et.al., op.cit., p.2. of institutional corruption is difficult to frame. He also added Bardhan (1997) and RoseAckerman (1999) arguments that corruption can be broadly defined as "the abuse of public power for private benefit" (Bardhan 1997; Rose-Ackerman 1999).

In the Indonesia's case, the corruptors may vary from the parliament (Angelina Sondakh), the law enforcement (Joko Susilo's bribery case) until the head of village (kepala desa) ${ }^{14}$. According to Law number 31/1999 jo. Law number 20/2000 about corruption article 2 subsection1, the definition of corruption is any person who unlawfully enriched themselves or another person, or a corporation that can be detrimental to state finance or economy. The government of Indonesia itself already took many actions to eradicate corruption, started from the policy an early anti-corruption education for children to establishing The Corruption Eradication Commission or known as Komisi Pemberantasan Korupsi (KPK). In the Jokowi's administration, the latest president has committed to the people of Indonesia that he will eradicate corruption by using e-Government. He wanted to make every single rupiah spent by the government to be track-able and searchable. His previous partner during his administration in Jakarta, Basuki Tjahja Purnama or known as Ahok (now the governor of DKI Jakarta) wants to implement e-budgeting throughout DKI Jakarta's public institution by 2015 but it have to face resistant

14 Tiga Kades di Mojokerto Terjerat Korupsi dan Pertambangan Ilega'l, news.detik.com, April 2, viewed on July $182015<\underline{\text { http://news.detik.com/> }}$ 
from the bureaucrats who thinks that it will reduce their "income" or job losses, but as a matter of fact Ahok only wants to eradicate the chance of corruption in terms of public budgeting (APBD).

Some people argue that ICTs is the ultimate tool to eradicate corruption and considered ICTs as a panacea to corruption. But the facts stated that ICTs could only helps to reduce the number of corruption and not a panacea. Literature indicates the cases of a number of Latin American and Indian states where petty corruption was reduced by employing e-governance ${ }^{15}$.

One of the proof why e-Government is not a panacea is because corruption still existing in Indonesia. Surabaya for instance, the second biggest city in Indonesia is still facing corruption issue although it is the first local government in Indonesia which used e-budgeting system. The latest corruption case happened in the subdistricts level ${ }^{16}$. Even in 2013, Surabaya ranked as the most corrupt city in East Java province ${ }^{17}$ while Bojonegoro region on the second place and Tuban region in the third place. The High Prosecutor of Surabaya noted 130 corruption cases happened in East Java during 2014 ${ }^{18}$.

$15 \quad$ Loc.cit., page 5-6

16 Surabaya distrICTs attorney named four suspects corruption in the case of misappropriation of funds MERR land acquisition compensation in Gunung Anyar. $<$ http://www.jawapos.com/ $>$

17 Duit Rp 83 Miliar 'Dimakan' Koruptor Jatim', Surabaya Pagi, 31 December 2013 <http://www. surabayapagi.com/>

18 Seminggu, Kejati Jatim Tetapkan 50 Tersangka Korupsi $<$ http://www.jawapos.com/ $>$

\section{Figure 2 : Corruption By Year Occurred} (Semester I) $^{19}$

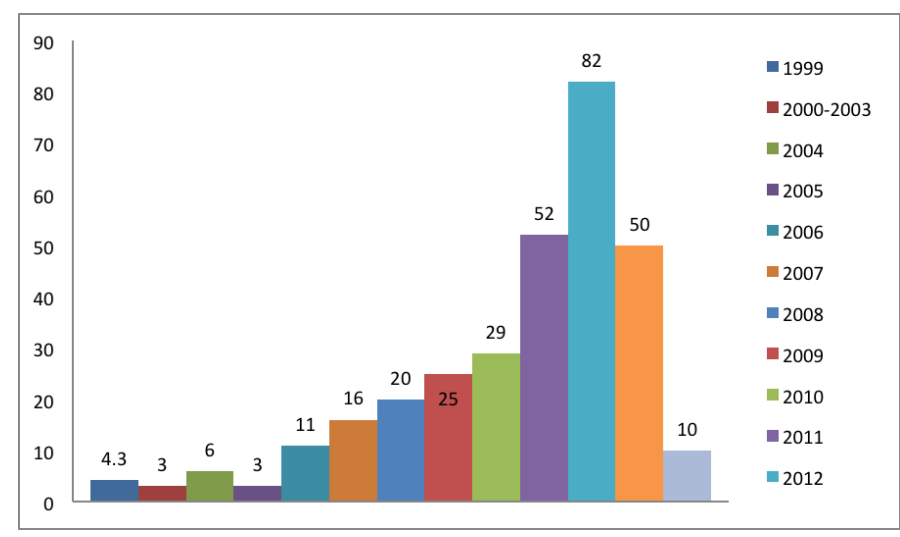

Figure 3 : Corruption by Year Occurred ${\text { (Semester II })^{20}}^{20}$

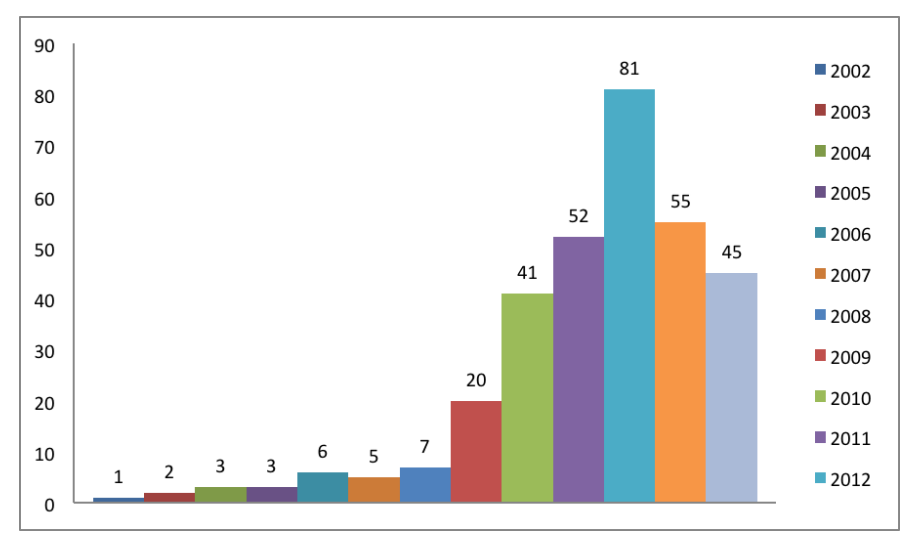

From 1999 until 2014, there has been a significant increased of corruption cases in Indonesia, whereas in 1999 the Government had issued Law on Corruption and then four years later followed by the new regulations regarding the implementation of e-Government throughout Indonesia. The first regulation should have been able to decrease the number of corruption cases and that should also happened to the ICTs regulation which had the indication to eradicate corruption.

Another reason, why ICTS is not a panacea to eradicate corruption is the security aspect.

\footnotetext{
$19 \quad$ ICW., op.cit., p.10

20 Loc.cit.p.10
} 
Government is the biggest data collectors. It collects almost every single details of our personal information in order to identify each and every single person on the country, to identify the country's issues such as the economic situation - why the state of our economic is in the depression state - and of course to make a better administration system. From the birth certificate, ID card, property certificate, tax form, our income per months and more to be named. Those are our personal information that we would be very careful to give it to someone else unless the subject is someone we knew. But since, it is the government who asked for our personal information and it is regulated in the law so we do not have the power to keep our personal information to ourselves but to willingly give it to the government. Furthermore, those data are stored in one single database on the internet because the government is trying to implement ICTs through e-administration. We have to remember one of the benefits using ICTs is efficiency. By storing those data into one online database, it would help public employees to categorize the citizen by specific codes or regions or anything. Since it is on the virtual world or the internet, the database might be endangered due to the fact that there are plenty of hackers 'surfing' on the internet, who might be able to hack the database and misused our personal information. For instance, on April $24^{\text {th }} 2004$, one of the famous hacker under the name Xnuxer or known as Schizoprenic managed to entered the TNP-KPU website ${ }^{21}$.

$21 \quad$ Kasus Peretasan yang Pernah Heboh di Indonesia, $<\underline{\text { http://www.lihat.co.id/> }}$
KPU or General Election Commission is a governmental institution which deals with general elections throughout the nation wide. This case is one of the proofs that the government failed to secure its website. Almost 98 percent of e-Government in Indonesia did not provide security system for the information contain on it. Deeper analyse will show that 100 percent of e-Government in Indonesia does not provide e-trust statement. E-trust statement is used to protect transaction by the government and the environment covered by e-Government including payment transaction or the use of digital signature ${ }^{22}$. So, before the government stored our personal information on the online database, they have to makes sure that the database is 100 percent secured and also provide e-trust.

Second, the human resources aspect. The adoption of ICTs in governmental systems creates an opportunity for the officers and staffs who understand and occupy skills of ICTs (e-literate) and at the same time block chances for those who do not understand ICTs. This is called as an up-skilling corruption ${ }^{23}$. For instance the college diploma forgery case of some high state officials. Every college diploma certificate must have its own serial number function as a code. It means one certificate could only have one serial number. Up-skilling corruption applied on this type of corruption. The officers who are e-literate in corporate with irresponsible subjects, changes

$22 \quad$ Evaluation of Provincial Capital E-Government Websites in Indonesia $<$ http://journal.unair.ac.id/>

23 Tutik Rachmawati, Does Technology Matter in Fighting Corruption?, 2012 
or made up a new serial numbers which is not released by the Directorate General of Higher Education (Direktoran Jendral Pendidikan Tinggi) through database of college (Pusat Data Perguruan Tinggi) but listed on the list. Most of the reasons they did so because it would be difficult to gained extra 'money' from their works while they believe that they pay check could not afford to pay daily needs anymore or as mentioned above about Joe Bologne's GONE theory. Therefore, BPPT must be vigilant to this new ability its officers and staffs might have.

There are also some changes in corruption after the implementation of ICTs in governmental area, computerisation does so by creating changes in one or more of four aspects. Heeks ${ }^{24}$ explained four changes due to the computerisation:

First of all from the aspect skills, computerisation is often associated with an 'up-skilling' of corruption, providing an opportunity for those with IT skills, and denying those without these skills. A decade or two decade ago, there could only be few people in the organization who occupied computer skills in fact computers were quite rare in that time compared to today's situation. Second, from the confidence aspect. Borrowing from the Panoptic vision, a mythical image may be promoted of the computer as an objective, all-seeing, all-knowing machine. This may cause some corrupt staff to lose confidence and to refrain

${ }^{24}$ Heeks., op.cit., p.7 from corrupt practices ${ }^{25}$. Third, with the advent of networked systems, such opportunities for access may greatly increases. Fourth, the mask of data quality and computer omnipotence makes some managers assume that IT removes the opportunities for corruption, i.e. that the Panopticon can operate without the need for human intervention. They may therefore fail to institute controls on computerised systems. This assumption provides greater autonomy for IT-literate staff.

Implementing e-administration is not a bad thing. In fact it is very efficient and effective, but the BPPT must be aware that corruption could still happen although the system prevent it. Therefore, to make e-administration still going on the BPPT should apply Jeremy Bentham (1978) theory of Panopticon Vision. Panopticon Vision ${ }^{26}$ is a concept of prison design which allows an observer to observe prisoners in which the prisoners will not be able to know that they are being secretly watched. In this state of affairs, the prisoners are conscious of being observed all the time. The consequence is that they behave with compliance under the existing law and regulation as well as norms. Or in other words, a constructed technology that allowed a single central unseen guard to observe the activity of all prison inmates ${ }^{27}$. The e-procurement system in local government and other government bodies is believed to be the

\footnotetext{
25 Ibid., p.7.

26 Rachmawati., op.cit.

27 Richard Heeks (Information Systems for Public Sector Management, 1998), p.3.
} 
realization of Panopticon vision idea. Such as e-procurement, the e-administration will be supervised by the public. But before we try to implement it, we have to remember Indonesia's internet penetration.

According to The Indonesian Association of Internet Service Providers (APJII) ${ }^{28}$ throughout 2014, they've marked 88 billion of internet users in Indonesia, which means there were 66 percent of Indonesia's citizens who are still cannot or do not have access to internet while the other 34 percents already capable to access internet. We're assuming these 34 percent of people live in the urban or suburban areas. Compared to other country in the South East Asia, Indonesia ranked on the first place of internet penetration ${ }^{29}$ while Singapore as the smallest country amongst South East Asia's countries has $104.2^{30}$ percent of internet penetration (Indonesia only 29.8 percent). Based on the fact above we may indicate that almost every single Singaporean has access to internet. The facts above indicates that it will be difficult to apply Jeremy Bentham theory because only 34 percents citizens of Indonesia able to access internet. Therefore the government of Indonesia must first decrease the number of people who are still non e-literate and build infrastructure that might helps to decrease the number of non e-literate people.

Asia Tenggara Punya Lebih Dari 190 Juta Pengguna Internet, $<\underline{\text { http: } / / \text { id.techinasia.com } />}$

29 Considering Indonesia has 242.452.952 people living on its land (BPS, 2010)

30 Asia Tenggara Punya Lebih Dari 190 Juta Pengguna Internet., op.cit.
Figure 4 : Indonesia Internet Users

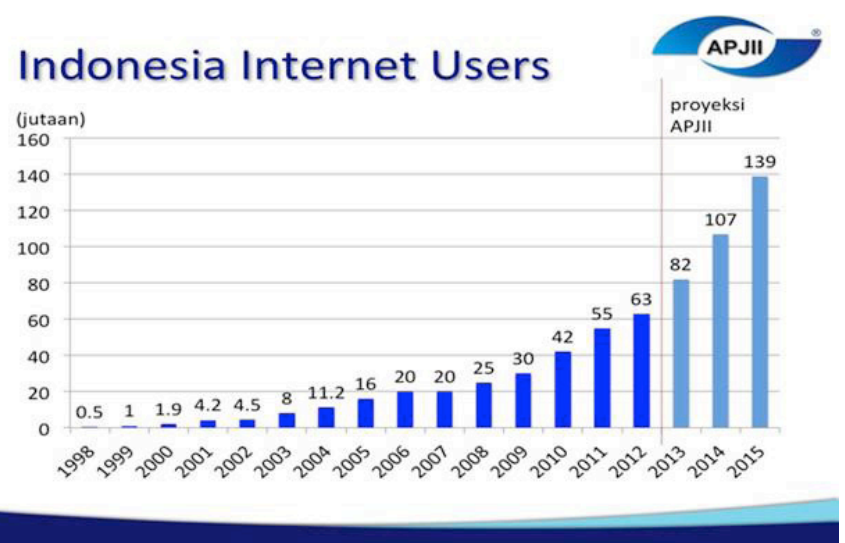

\section{CONCLUSION}

Based on the elaboration above, it can be conclude that e-Government is not a solution to eradicate corruption. E-Government will only help to the government to transform public services more accessible, efficient, effective and transparent. By using e-Government, especially the e-budgeting system, the government hopes that all public institution can be more transparent in term of public budgeting. Even though ICTs does matter to decrease corruption although it will not bring specific impact (in the case of Surabaya City, for instances).

\section{RECOMENDATION}

Although corruption cases are still happening in almost every public sector in Indonesia, there will always a hope that one day, corruption will not be an issue anymore. As the Transparency International Indonesia (a global coalition against corruption) published on their website, Indonesia now ranks 107 on the most corrupt country on the world, with score rose 2 point (2013: 32 - 2014: 34) as well as the ranks rose 7 point $(2013: 100$ - 2014:107) from 
last year ${ }^{31}$. This data proofed that Indonesia has succeeded in terms of reducing the corruption rate. But we cannot just sit and relax after knowing that Indonesia rose seven points because we still have loads of homework to be done.

\section{REFERENCES :}

1. Anh-Minh Do, Asia Tenggara Punya Lebih Dari 190 Juta Pengguna Internet (Infografik), < $\underline{\text { http:// }}$ id.techinasia.com/ $>$ viewed on May 6 2015.

2. Anna, Nove E.Variant, Dyah Puspitasari, Endah Fitriyah Mannan \& Fitri Mutia, 'Evaluation of Provincial Capital E-Government Websites in Indonesia', Universitas Airlangga, viewed on July $212015 \leq$ http:// journal.unair.ac.id/>

3. Center For Democracy \& Technology 2002, The E-Government Handbook For Developing Countries, Center For Democracy \& Technology.

4. Divisi Investigasi Dan Publikasi ICW 2014, Tren Pemberantasan Korupsi 2014.

5. Fat 2015, 'Tiga Kades di Mojokerto Terjerat Korupsi dan Pertambangan Ilega'1, news.detik.com, April 2, viewed on July $182015<$ http://news.detik. $\underline{\mathrm{com} />}$

31 Corruption Perception Index , $2014 \leq$ http://ti.or.id/ index.php/>
6. Gone Theory, https://roeshanny. wordpress.com/2009/02/04/gonetheory/ viewed on May 62015.

7. Heeks, Richard 1998, 'Information Systems for Public Sector Management Working Paper Series', Information Technology and Public Sector Corruption, Number 4, page 7.

8. Jamshed J. Mistry and Abu Jalal 2012, 'An Empirical Analysis of the Relationship Between E-Government and Corruption', The International Journal of Digital Accounting Research Vol. 12, p. 145, viewed November 28 2015, < http://scholar.google.co.id />

9. Jin-Wook Choi 2014, 'E-Governemnt and Corruption: A Cross-Country Survey', World Political Science Review, Volume 10, Issue 2, p.217, viewed 28 November $2015<\underline{\text { www }}$. search.proquest.com>

10. Kasus Peretasan Yang Pernah Heboh di Indonesia, Viewed on July $20<\underline{\text { http:// }}$ www.lihat.co.id/>

11. Law number 31/1999 about Corruption.

12. Margareth, Rouse, 'ICTS (information and communications technology-or technologies) definition', viewed May 62015 http://searchcio.techtarget.com/

13. Mulyonim Budi, Hendarwanto Abidin 2013, 'Duit Rp 83 Miliar 'Dimakan' Koruptor Jatim', Surabaya Pagi, 31 December, viewed on July 202015 $<\underline{\text { http://www.surabayapagi.com/ }>}$ 
14. Perdana, Putra Prima 2015, ' Kini, 24 Jenis Izin di Bandung Bisa Diajukan Secara "Online" Kompas, May 28, viewed July $182015<$ http://regional. kompas.com/>

15. Priyono, Eko 2015, 'Seminggu, Kejati Jatim Tetapkan 50 Tersangka Korupsi', Jawa Pos, 15 Januari, viewed on May 102015 http://www.jawapos.com/

16. R.D.Pathak Gurmeet Singh and Rakesh Belwal 2007 'Governance \& Corruption-Developments and Issues in Ethiopia', Vol.7, Issue 3, p.5, viewed 28 November 2015, <www.search. proquest.com>

17. Rachmawati, Tutik 2012, 'Does Technology Matter in Fighting Corruption?', < com/> viewed on July 212015.

18. Roux, Laetitia 2015 'Public Service Values and E-administration: An Explosive Mix? Illustration Drawing On The Case of The Family Allowance Funds (Caisses d'Allocations Familiales) in France', France: International Review of Administrative Sciences, Volume 81, Issue 2, page 228.

19. Transparency International Indonesia 2010, Corruption Perception Index 2014, viewed on July $212015<\underline{\text { http:// }}$ ti.or.id/> 